\title{
FUSARIUM LATERITIUM (NEES) AS AN AGENT OF FUNGEMIA IN A PATIENT INFECTED WITH THE HUMAN IMMUNODEFICIENCY VIRUS (HIV)
}

\author{
Idalina Inês Fonsêca Nogueira Cambuim ${ }^{1}$; Rejane Pereira Neves ${ }^{1 *}$; Lusinete Aciole de Queiroz ${ }^{1}$; \\ Oliane Maria Correia Magalhães ${ }^{1}$; Débora Maria Massa Lima ${ }^{1}$
}

\author{
${ }^{1}$ Departamento de Micologia, Centro de Ciências Biológicas, Universidade Federal de Pernambuco, Recife, PE, Brasil
}

Submitted: July 26, 2006; Returned to authors for corrections: October 05, 2006 Approved: February 12, 2007.

\begin{abstract}
Emerging fungal pathogens are associated with significant morbidity and mortality in the immunocompromised host. The association of fungi from the Fusarium genus with human infection in uncommon. The objective of this paper is to report the first case of fungaemia caused by Fusarium lateritium in a 42-year-old HIV-infected patient.
\end{abstract}

Key words: Fungaemia, Fusarium lateritium, HIV-infection, immunocompromissed

Members of the genus Fusarium are ubiquitous fungi uncommonly associated with human infection. However, they have been described as emerging fungal pathogens associated with significant morbidity and mortality in immunocompromised hosts $(2,6)$.

Human infection usually occurs as a result of inoculation of organism through the body surface, thus causing skin infection, onychomycosis, keratitis, fungaemia, endophtalmitis and arthritis. The disseminated form may occur in patients with severe immunodeficiency (2), although rarely found in HIVpositive or AIDS patients (4).

Species of Fusarium cause spread illness, but the invasive form has recently emerged as the more common etiological agent after solid-organ transplantation $(9,10)$. Considering the increasing number of cases of HIV and the susceptibility to opportunistic mycosis, the objective of this study is to relate the first case of fungaemia caused by Fusarium lateritium in a HIV-positive patient.

The patient is a 42-year-old Brazilian male, living as a gardener in Recife Metropolitan Region - Pernambuco State, Brazil. Upon arrival to the Hospital Correia Picanço ambulatory, Recife, PE, Brazil, the patient was submitted to physical examination, and skin lesions, necrotic nodules, axillar furuncle, fever, erythematous papules and abscesses were observed.
Laboratory tests revealed $434 / \mathrm{mm}^{3} \mathrm{CD} 4$ blood cells counts and 4.670 copies $/ \mathrm{mm}^{3}$ of viral load.

Venous blood samples were aseptically collected in three consecutive days, by venipuncture into VACUTAINER $®$ tubes using EDTA anticoagulant. The samples were subcultured in biphasic Brain Heart Infusion (BHI) and incubated at $36.5^{\circ} \mathrm{C}$ for five days. The mycological diagnosis was carried out in the Medical Mycology Laboratory of Federal University of Pernambuco, Recife, PE, Brazil.

Pure cultures were transferred to the surface of potato dextrose agar medium for taxonomic identification. The isolates were identified based on macroscopic and microscopic properties $(1,8)$.

Among the numerous colonies on potato dextrose agar maintained at room temperature, one attained a diameter of $2.5 \mathrm{~cm}$ after four days. The fungus presented slow growth and sparse aerial mycelium. Macroconidia were long with parallel walls, and the apical cells had a distinct beak shape, while basal cells were foot-shaped. Microconidial shapes varied from oval to spindle and kidney-shaped. Branched and unbranched monophialides were observed, and chlamydospores appeared singly (Fig. 1). This fungus was subsequently identified as $F$. lateritium based on Booth and Nelson $(1,8)$. The strain was deposited in the URM Culture Collection of the Department of

*Corresponding Author. Mailing address: Rua Jose Paraíso, 135 - apto. 01 - Boa Viagem. 51030-390, Recife, PE. Tel.: (+5581) 2126-8570 - Fax: (+5581) 2126-8482 E-mail: rejadel@yahoo.com.br ou idalinacambuim@hotmal.com 


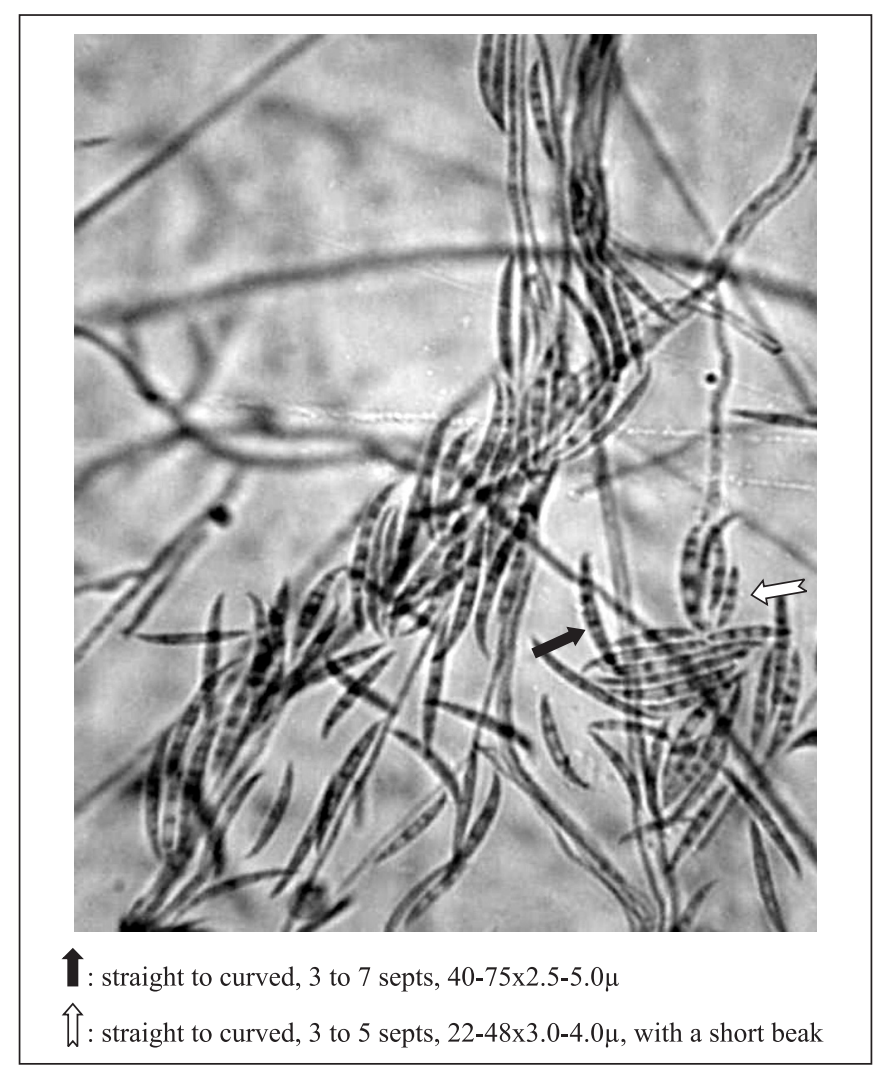

Figura 1. Fusarium lateritium macroconidia after four days on potato dextrose agaer at room temperature.

Mycology, Biological Sciences Centre, Federal University of Pernambuco, Brazil, under number 4800.

These results suggest that $F$. lateritium can be an etiological agent of fungaemia. The case described here illustrates the importance of an accurate identification of the agents, especially in immunosuppressed patients. The fungaemia characteristics suggest that acquisition of Fusarium species by immunocompromised patients can be consequence of the frequent exposure to the aethiological agent, such as occurred with this patient, who works as a gardener.

The proper identification of Fusarium species and other filamentous fungal opportunists is important for establishment of the correct clinical causative agent and the proper antifungal therapy.

F. lateritium is an emergent pathogen in patients with immunodeficiency and its presence in these type of host can not be considered colonization, as there is an important risk of invasive infection.

Fusarium species has been isolated from human infection, although no literature is available on the isolation of F. lateritium as agent of fungaemia. However this species was isolated from one keratitis case and exhibit mycotoxin secretion and ability to cause opportunistic infections $(3,7)$. This is the first time that $F$. lateritium is reported in the blood in a HIV-infected patient.

\section{ACKNOWLEDGEMENTS}

This work was supported by CAPES.

\section{RESUMO}

\section{Fusarium lateritium (NEES) como agente de fungemia em um paciente infectado com o vírus da imunodeficiência humana (HIV)}

Patógenos fúngicos emergentes estão associados com morbidade e mortalidade no hospedeiro imunocomprometido. O gênero Fusarium raramente está associado com infecção humana. O objetivo deste estudo é relatar o primeiro caso de fungemia causada por Fusarium lateritium em um paciente infectado pelo HIV com 42 anos de idade.

Palavras-chave: Fungemia, Fusarium lateritium, infecção HIV, imunocomprometido.

\section{REFERENCES}

1. Booth, C. (1971). The Genus Fusarium Commonweath Agricultural Bureaux. England: Commonweath Mycological Institute, farnham Royal, Bucks, England.

2. Dignani, M.C.; Anaissie, E. (2004). Human fusariosis. Clin. Microbiol. Infect., 10, 67-75.

3. Guarro, J.; Gene, J. (1995). Opportunistic fusarial infections in humans. Eur. J. Clin. Microbiol. Infect. Dis., 14(9): 741-754.

4. Jensen, T.G.; Gahrn-Hansen, B.; Arendrup, M.; Bruun, B. (2004). Fusarium fungaemia in immunocompromised patients. Clin. Microbiol. Infect., 10(6): 499-501.

5. Marasas, W.F.O.; Nelson, P.E.; Toussoun, T.A. (1984). Toxigenic Fusarium Species: Identity and Toxicology. Pennsylvania State University Press, University Park.

6. Musa, M.O.; Al Eisa, A.; Halim, M. et al. (2000). The spectrum of Fusarium infection in immunocomprimised patients with haematological malignances and in non-immunocompromised patients: a single institution experience over 10 years. $B r . J$. Haematol., 108(3): 544-548.

7. Naiker, S.; Odhav, B. (2004). Mycotic keratitis: profile of Fusarium species and their mycotoxins. Mycoses, 47(1-2): 50-56.

8. Nelson, P.E.; Toussoun, T.A.; Marasas, W. (1983). Fusarium species - An Illustrated Manual for Identification. London, The Pennsylvania State University Press.

9. Nucci, M.; Anaissie, E. (2002). Cutaneous infection by Fusarium species in healthy and immunocompromised hosts: implications for diagnosis and management. University Hospital, Universidade Federal do Rio de janeiro, Brasil. Clin. Infect. Dis., 35, 909-920.

10. Sampathkumar, P.; Paya, C.V. (2001). Fusarium infection after solid-organ transplantation. Clin. Infect. Dis., 32, 1237-1240. 